\title{
The Bologna Process Goes East? from "Third Countries" to Prioritizing Inter-regional Cooperation Between the ASEAN and EU
}

\author{
Que Anh Dang
}

\section{Introduction}

Over the past 15 years, the Bologna Process (BP) has evolved from being a pan-European project to a significant regional reform of higher education which exerts its influence beyond the borders of Europe. Initially other regions, such as North America, observed this re-organization of Europe's higher education structure with some scepticism (Clark 2014), but more recently, the creation of a European Higher Education Area (EHEA) and a European Research Area (ERA) has increased the interest across the world, especially Asia. The Association of Southeast Asian Nations (ASEAN) and ASEAN+3 (China, Japan and the Republic of Korea) have been observing the development of the Bologna Process and viewing the Bologna Process, EHEA and ERA as a useful model for their regional higher education reforms. Japan and China have participated in all three Bologna Policy Forums since 2009. These countries also fear that the 'attractive' European higher education region will expand its links to ASEAN to the detriment of their position in ASEAN and in the international marketplace (Kamibeppu 2013).

The Bologna Process has inspired the ASEAN ministers to set an ambitious plan in 2008 with an aim to achieve greater regional harmonization involving 6500 higher education institutions and 12 million post-secondary students (ICEF 2014) about the same size as the EHEA. The region began a process of building a 'Common Space for Higher Education' contributing to the establishment of the ASEAN Economic Community. The European Union (EU) has been supporting the ASEAN regional integration process and education is one of the top priorities in the interregional EU-ASEAN dialogues. These developments raise important questions: Through which mechanisms do the Bologna ideas and policy instru-

Q.A. Dang (ه)

University of Bristol, Bristol, UK

e-mail: qa.dang@bristol.ac.uk

(C) The Author(s) 2015

A. Curaj et al. (eds.), The European Higher Education Area,

DOI 10.1007/978-3-319-20877-0_47 
ments become a model for the regionalization of ASEAN higher education? Why does ASEAN regional higher education matter to the EHEA and vice versa? What are the differences of the 'ASEAN common space for higher education' and the EHEA?

Most regional studies on ASEAN and the EU favour the theory of policy diffusion, which describes the EU-style institutions as a putative paradigm for ASEAN regional integration (Allison 2013; Jetschke and Lenz 2013; Jetschke and Murray 2012). Some scholars in educational sociology also claim that regionalization of higher education in Asia aspires to replicate the Bologna Process (Chao 2014a; Vögtle and Martens 2014). These scholars tend to see Asian countries as passive recipients of ideas and norms, and somewhat downplay the role of the agency of local policy actors. This paper draws on both policy diffusion literature in political science and social constructivist work in critical policy studies to posit that policies are not merely transferred through diffusion over space or across policymaking sites, but their form and effect are also transformed through ongoing mutation processes (Peck 2011; Peck and Theodore 2010, 2012). The paper also highlights the role of contexts and of the policy actors-'localizers' who reconstruct external policy ideas and transform them into their local 'cognitive priors' (Acharya 2009).

Tracing the evolution of the ASEAN regional cooperation in higher education over the last decade through an empirical study of ASEAN policy makers, this paper argues that ASEAN actively constructs a nascent 'ASEANess' higher education region and can potentially change the nature of engagement with the European counterpart. From being a collection of 'third countries' in Brussels' language, ASEAN becomes a strategic partner in inter-regional cooperation with the Bologna countries that are also members of the EU.

In line with the EU's external policies and with a growing emphasis on "internationalization" in many European national education policy contexts, the Bologna Process increasingly prioritizes its dialogues and negotiations with regions over individual countries, thus expands its outreach to a larger scale. Since the European Commission joined the Bologna Process, Bologna cooperation with other regions seems to create a political space for the Commission to act on behalf of its member states in higher education. The 40-year regional ties between ASEAN and the EU also serve as a foundation for higher education, science and technology to become a priority area of cooperation between the two regions. This point was explicitly mentioned in the plan of action to strengthen ASEAN-EU partnership for the period 2013-2017. ${ }^{1}$ For all these reasons, this essay will focus only on the regional dialogues between the $\mathrm{EU}$ and the $\mathrm{ASEAN}+3$, given the extensive memberships of the Bologna Process.

The paper is organized in five sections. Following the introduction, the second section lays out the regional architecture of ASEAN higher education landscape. The third section recaps the history of the Bologna external dimension and draws on the theoretical literature on policy diffusion, policy mobility, and constitutive

\footnotetext{
${ }^{1}$ http://eeas.europa.eu/asean/docs/plan_of_action_en.pdf (accessed on 23 December 2014).
} 
localisation to analyze how, by whom and to what extent the Bologna Process has become a model of regionalization of the ASEAN higher education. The fourth section presents the empirical cases and qualitative data collected by the author at regional forums in order to depict the distinctive features, the emergence and developments of regional projects in ASEAN. The last section summarizes the main arguments and draws some concluding remarks on the possible changing nature of EU-ASEAN interregional cooperation in higher education.

\section{Regionalism and Higher Education in ASEAN}

\subsection{Regionalism in ASEAN}

ASEAN was established in August 1967 in Bangkok by five founding membersIndonesia, Malaysia, the Philippines, Singapore and Thailand. Brunei joined in 1984, whereas Vietnam, Laos, Myanmar and Cambodia joined in the 1990s. There are multiple theoretical perspectives on the ASEAN regionalism. Realists see the establishment of ASEAN as an act of power seeking (Rüland and Jetschke 2008). The ASEAN regional aspirations were understood by realists as a group of small, weak states, which do not possess the economic or military resources to be a dominant regional power, who formed themselves in a regional grouping as the only way to increase its collective bargaining power and exercise its political influence (Narine 1998). The principles of 'non-interference into the internal affairs of the members' and 'consensual decision-making' remain crucial norms (Jetschke and Murray 2012). This informal and non-binding regional institution has been known as the 'ASEAN way' for over forty years which has also been, rightly or wrongly, criticized for its ineffectiveness from a Western liberal perspective (Wong 2012).

Constructivists see regions as social, economic and political constructions based on material transactions and a degree of interdependence (Dent 2012; Rüland 2010), with its shared norms, identities, practices and institutions facilitating 'regioness' (Hettne 2005). Acharya (2009, p. 21) names these factors as 'cognitive priors' which determine and condition an individual or social group's receptivity to new norms. He also points out that the cognitive priors of nations or regions in international relations could be built around traditional culture, historical memory, practices of statecraft and diplomatic interaction patterns (ibid). In other words, the colonialism and decolonialism periods, the vagaries of the Cold War and the Asian financial crisis in the late 1990s has profoundly influenced the ASEAN regionalism as Stubbs (2008) argues. Seizing the opportunity of the ambiguity created by the ending of the Cold War, ASEAN not only enlarged its membership, but also established and institutionalized other multilateral dialogues, such as the Asia-Europe Meeting (ASEM) in 1996, ASEAN Plus Three (ASEAN+3) in 1997 and the East Asia Summit in 2005. In the first instance, the ASEAN+3 cooperation 
was a reaction to the ASEAN financial crisis and to strengthen the East Asia Economic Caucus by keeping the United States out (Doidge 2011), then it quickly led to a further series of dialogues between the leaders, ministers and seniors officials (Dent 2012; Yeo 2010). Cooperation also extended from economic and financial areas to many other areas, including education. Noticeably, from around 2005 when the Bologna Process increasingly exerted its influence on global higher education beyond Europe, the agenda of ASEAN+3 has included higher education at government level.

\subsection{ASEAN Regional Higher Education}

The ASEAN regional higher education architecture consists of two main institutions. The first is the Southeast Asian Ministers of Education Organization (SEAMEO) established before ASEAN in 1965 to promote cooperation in education, science and culture in the region. The second is the emerging or re-emerging ASEAN framework for educational cooperation. After a long interval from the first ASEAN education ministers' meeting (ASED) in 1977 which called for a comparative study of the education systems of member countries to set up effective collaboration, and exchanged views on the concept of an ASEAN university (ASED 1977), the ASEAN education ministers have resumed their meetings on a regular basis since 2006. In the first six years, ASED meetings were held back-to-back with the annual SEAMEO Council conference.

The turning point was the 15th ASEAN Summit in 2009 in Thailand, which gave new momentum to the regional education cooperation for "promoting understanding among ASEAN people and ensuring the competitiveness of ASEAN Community in the global market" (ASEAN 2009). The focus has shifted from intra-regional solidarity through education to enhancing the identity of 'ASEAN people' and increasing the role and power of education in the political and economic arena. Moreover, the 5th ASED meeting in 2010 also emphasized the necessity of 'strengthening, deepening and widening educational cooperation within ASEAN and outside the region" (ASED 2010), namely the ASEAN+3 under the work plan (2010-2017) and the East Asia Summit countries, including China, Japan, the Republic of Korea, Australia, India, New Zealand, with the United States and Russia joining in 2011. Since 2012, the ASEAN education ministers have organized their own meetings biennially, separate from those of SEAMEO, and invited the ASEAN+3 and East Asia Summit education ministers to join. There was no announced reason for this separation, but my observations support arguments that the ASEAN identity was diluted when ASED was only a 'side-event' of the SEAMEO, and the agendas and the memberships of ASED and SEAMEO became increasingly different. Furthermore, as the ASEM education process gathered pace, ASEAN+3 education cooperation aspires to consolidate itself to become a more cohesive region to act effectively at the Asia-Europe interface. Last but not least, the Plus Three countries support the ASEAN regional integration in all spheres 
including higher education, but their national interests in this endeavour are not concealed. With their ageing populations, Japan, China and Korea are increasingly interested in the brainpower of the ASEAN's young talented students and scholars for their knowledge economy missions. Therefore, while the agenda of ASED centres mainly around the ASEAN countries' commitment to achieving the Millennium Development Goals, Education for All by 2015 (ASED 2014), the discussion on higher education dominates the meetings of ASEAN+3 and it was also fuelled with the range of initiatives and projects proposed by the countries, such as students mobility, quality assurance, university networks, ASEAN research clusters and citation index, rectors' conference, and the ASEAN cyber university (APT 2014).

The history and development of the ASEAN regional education cooperation over 40 years and the ASEAN+3 cooperation in the last decade have consolidated the region's own model of integration, which is based on inter-governmental dialogues, voluntary commitments, regular meetings and statements. It would be implausible to claim that the 15-year old Bologna Process is the template for regional policy coordination, as Vogtle and Martens (2014) concluded in their recent research. Although the substance of the Bologna action lines may be seen resembled in the recent ASEAN regional talks, this new development occurs due to the mutual interests from the EU seeking to diffuse the Bologna policy and from the ASEAN looking to learn from it. Notably, the EU has shown an interest in what is happening in ASEAN and Germany inaugurated the Asia-Europe Education Ministers' biennial forum on higher education in 2008. ASEAN has also acknowledged that the Bologna Process serves as an inspiration and reference for ASEAN's own higher education harmonization. ASEAN officials often indicated that they studied the EU regional education policies in order to avoid the same mistakes and pitfalls (Dang 2013).

\section{The Bologna Process Goes East: From Policy Diffusion to Policy Mutation}

\subsection{The Bologna Goes East}

Three years after the Bologna Declaration was signed in 1999 by 29 European countries, the Bologna Follow Up Group (BFUG) drafted a report on "attractiveness, openness and cooperation" as the three main entities of the Bologna Process 'external dimension', which then became a point on the agenda of the Bologna Ministers from their Berlin meeting in 2003 onwards. In the Bologna language, 'Attractiveness' referred to quality, transparency, diversity and visibility, 'Openness' called for joint effort to make European higher education open to students from all over the world. And 'Cooperation' was to promote the 'Bologna idea' of regional cooperation and integration through dissemination of experiences 
with other regions, although the goal was not to directly associate non-European countries to the process (BFUG 2002). From an unintentional idea of making the Bologna Process a model for regional reform of higher education (Zgaga 2006), the Bologna countries became proactive in promoting the Bologna philosophy by "opening their seminars and conferences to representatives of other regions" (Berlin Communique 2003) and seeing "the need to identify partner regions and intensify the exchange of ideas and experiences with those regions" (Bergen Communique 2005 , emphasis added). The 'external dimension working group' was also set up in 2005-2006 to collect and analyze reactions and echoes of various kinds from other parts of the world, such as ASEAN and the African Union. Regional cooperation with the "outer world" has also created a new space for the European Commission to act as a supranational entity. The Commission has provided financial support to a number of projects with ASEAN since the 2000s, such as the ASEAN-EU University Network Programme (AUNP 2000-2006), ${ }^{2}$ the Asia-Link programme (2002-2006), Asia Windows (2004), the EU-Asian Higher Education PlatformEAHEP (2008-2009). These projects and the policy dialogues and networks that they generated could be seen as vehicles to diffuse the European policies of higher education.

\subsection{Policy Diffusion}

Börzel and Risse $(2009,2012)$ note that the EU promotes regionalism as a distinct European idea and the EU sometimes constructs new regions to interact with. Using examples from political science, the authors explain that in order to spread its idea of regional integration to other regions, the EU has developed five sophisticated diffusion mechanisms which exert direct and indirect influence (Table 1).

The first mechanism uses coercive authority, legal or physical force to impose ideas on the recipients who have no choice but to accept. This mechanism may only be relevant to the internal diffusion of ideas in the Europeanization process where members (or candidates) are obliged to comply with the EU laws and institution. By contrast, ASEAN has its own method of integrating new members, by accepting them as the 'persons' they are instead of demanding domestic structural adjustments from them (Jetschke and Murray 2012).

The second mechanism concerns diffusion of ideas through the manipulation of utility calculations by giving negative or positive incentives. The promoters of ideas use this approach in order to achieve certain goals, for example gaining access to new markets or preventing negative externalities, such as civil wars in neighbouring countries, by providing financial or technical assistance or sanctions. In practice, this mechanism manifests itself in the form of 'capacity building', which provides

\footnotetext{
${ }^{2}$ https://globalhighered.files.wordpress.com/2010/02/aunp.pdf (last accessed on 23 December 2014).
} 
Table 1 Mechanisms of diffusion

\begin{tabular}{l|l|l}
\hline Mechanisms & Rationality of action & Modalities and tools \\
\hline Direct influence & 1. Legal and physical & 1. Coercive authority \\
1. Coercion & imposition & 2. Incentives, sanctions \\
c. Manipulation of utility & 2. Instrumental & 3. Normative pressure, \\
calculations & rationality & authoritative model \\
3. Socialization & 3. Normative rationality & 4. Reason-giving \\
& 4. Communicative & \\
& Rationality & \\
\hline
\end{tabular}

Indirect influence

5. Emulation

\begin{tabular}{l|l}
\hline (a) Functional emulation & (a) Instrumental \\
(b) Lesson-drawing & rationality \\
(c) Mimicry & (b) Normative rationality \\
& (c) Mimetic/normative \\
& rationality
\end{tabular}

1. Comparison and competition

2. Best practice

3. Demand-driven

Source Adapted from Börzel and Risse (2009, 2012)

the targeted recipients with additional resources enabling them to make choices or in the form of 'conditionality', which aims to manipulate the cost-benefit calculations of the recipients through negative or positive incentives. For example, the EU seriously downgraded its relations with ASEAN, suspending meetings and avoiding high level contacts in the late 1990s due to the accession of Vietnam, Laos, Cambodia and Myanmar. This could be seen as a subtle form of negative conditionality. Power asymmetry is the key factor in these direct influence mechanisms. Hence, the less asymmetrical the power relationship between the EU and target countries or regions is, the less effective direct influence mechanisms of diffusion in inducing institutional change are (Börzel and Risse 2012, p. 203). For example, the lack of membership perspective of neighbouring countries seriously curbs the ability of the EU to manipulate their utility calculations. Since the EU has no or little ability to force non-members into compliance with its standards and institutional prescriptions, it relies more on other mechanisms, such as 'soft' incentives, socialization and persuasion if it wishes to influence regional institutional change (Jetschke and Murray 2012). In practice, the EU increasingly uses a co-funding modality.

The third mechanism-socialization - is based on normative rationality and works through diffusing authoritative norms and models which are aimed at different types of learning on the side of the recipients. Diffusion scholars portray policy makers of other regions or third countries as rational, calculating subjects engaged in 'voluntaristic' forms of policy learning through socialization. In practice, the EU often diffuses its policies in complex processes in which several mechanisms are at work simultaneously. There are cases of coerced transfer executed in the context of asymmetrical power relations combining socialization and incentives in the form of 'capacity building' for direct export of the European 
Bologna model. For example, since 2011 the EU has allocated a total budget of Euro 9 million to support the "Intra-ACP Academic Mobility Scheme", which sets up university consortia and facilitates student and staff mobility within Africa and in the Caribbean and Pacific regions. Similarly, in early 2014 the EU also launched a project called "the European Union Support to Higher Education in ASEAN Region (EU SHARE)" with a budget of Euro 9.6 million. This programme will support ASEAN to develop regional frameworks of quality assurance, qualifications framework and credit transfer. Through the incentive and professional socialization, the EU will share its experience and expertise on the Bologna Process and the development of the EHEA (EU SHARE 2014). These projects could be seen as 'funded emulation'.

The fourth mechanism is persuasion, which promotes ideas as legitimate or true by reason-giving and logical arguments. Non-state international organizations often play an important role in this mechanism, for example the European University Association (EUA) and the European Network of Quality Assurance in higher education (ENQA) are active promoters of the Bologna model in and outside Europe. Often, the EU diffuses its ideas via socialization and persuasion in institutionalized patterns of political dialogues with third countries and other regions. The Bologna Policy Forum, Tuning (China, Japan, Russia, Latin America, USA, Africa) and the ASEM education forum are examples of such influential political dialogues.

Finally, the fifth mechanism is emulation, which does not require an active promotion of ideas, but relies on the principle of competition and comparison. The EU encourages competition among the countries and regions seeking closer relations with the EU, because competition does not only diffuse ideas as normative standards for political or economic behaviour, but also spreads causal beliefs, for example by learning from best practice, actors borrow ideas (emulation) to improve their performance in comparison to others. According to Börzel and Risse (2009, 2012), regional organizations across the globe have increasingly mimicked the EU. In particular, the ASEAN has imitated parts of the EU institution (e.g. the committee of permanent representatives, the human rights commission were added to the ASEAN's institutional structure) in order to increase its international recognition and reputation (Jetschke and Murray 2012; Wong 2012). The authors also posit that diffusion is "demand-driven by actors who seek to bolster their effectiveness and legitimacy" (Börzel and Risse 2009, p. 9). In a similar vein, sociological institutionalism analyzes the reproduction or imitation of organizational structures by emphasizing the patterns of institutional isomorphism shared across different countries, but in such case diffusion depends on the organizational fields in which institutions operate, the role of shared beliefs, legitimacy for an organizations' survival and cultural ties between actors (DiMaggio and Powell 1983).

The major limit of the diffusion approach is that it tends to ignore the role of agency in what it portrays as almost a passive process. It is deficient in explaining how the ASEAN policy makers filter the Bologna ideas and transform them into their own regional context. This diffusion approach also neglects the robustness of 'firewalls' or political resistance along the diffusion path. These diffusion scholars 
fail to mention that there are policies that do not diffuse, even in an interdependent world. Hence, understanding what does not diffuse should be as important as understanding what does (Solingen 2012). With regard to outcomes of policy diffusion, for instance 'regional institution building', the diffusion approach is only attentive to the formal structure, such as the emergence of regional organizations, but without explaining the efficacy of the organizations (Jetschke and Lenz 2013). It also focuses narrowly on the idea of policy convergence as the end result of a diffusion process, with little attention to policy implementation, wider consequences and variation in institutional outcomes at the receiving end (Dale and Robertson 2012; Peck 2011).

\subsection{Policy Mobility and Mutation}

While the diffusion literature defines policy diffusion as a distinctively conspicuous category of border-crossing practice, the occurrence of which is traced to superior performance or success stories in exporting jurisdictions, policy mobility scholars see the mobilization of policies as the reconstruction of power relations between jurisdictions. That is because the very movement of policies remakes the connections between sites of policy inventors and policy recipients through (re)constructing policy networks and circulatory mechanisms (Peck 2011; Peck and Theodore 2010, 2012). These authors also argue that context matters in the sense that political landscapes are more than just empty space where diffusion takes place; they are reconstructed through the back and forth traffic of policy norms and practices. Unlike the diffusion approach which sees policies diffuse from the capitals of innovators/inventors to the hinterlands of emulators, the term 'policy mobility' connotes the multiplicity of processes, in which policy regimes are becoming more deeply and relationally interconnected through global networks of policy actors (Peck 2011, pp. 1-3).

Peck and Theodore (2010) and Peck (2011) outline the five key features of the policy mobility approach as follows:

- First, policy formation and transformation are seen as socially constructed processes, as fields of power. Policy transfer is not reduced to a process for transmitting best practices, but is about adaptive connections, deeply structured by enduring power relations and shifting ideological alignments. Policy mobility also entails the reconstitution of fields of power and the establishment of connections between policy actors and policymaking sites (e.g. enrolment of 'audience' who are policy supporters and followers or emulators).

- Second, policy actors are not conceptualized as lone learners, but as embodied members of epistemic, expert and practice communities/networks. They are 'travelling technocrats' and 'policy entrepreneurs', who are not only high-level agents of elite institutions, but also mid-level technocrats (Temenos and McCann 2013), such as a web of governmental policy makers, regional and 
national experts, university international officers and NGO consultants in the Bologna Process. Their peripatetic forms of expertise are also transformed by the journeys that they make.

- Third, mobile policies rarely travel as complete 'packages', they move in bits and pieces - as selective discourses, inchoate ideas, and synthesized modelsand they therefore 'arrive' not as replicas, but as policies already in transformation. They do not simply travel, intact, from sites of invention to sites of emulation. Instead, through their very movement they remake connections between these sites, evolving in form and effect through mobility (Peck and Theodore 2012, p. 23). That means high rates of policy mobility are not leading to some sort of policy monopoly because new forms of uneven spatial development and new localizations are constantly being produced. Hence, there is no expectation of global convergence in these open-ended processes.

- Fourth, the resulting dynamic in the policy making process is not one of simple emulation and linear replication across the policymaking sites, but a more complex process of nonlinear reproduction. Policies will therefore mutate and morph during their journeys.

- Fifth, the spatiality of policy making is not "flattened into some inert plane or transaction space, marked only with jurisdictional boundaries, across which transfers occur, but in terms of a three-dimensional mosaic of increasingly reflexive governance shaped by multi-directional forms of cross scalar and interlocal policy mobility" (Peck and Theodore 2010, p. 170).

In sum, diffusion scholars tend to be preoccupied with accounts of rationally selected best (or better) practices moving between jurisdictional spaces. They neglect the fact that the policy making process involves "a series of contexts from the production of the policy to its movement and new point of fixity" (Dale and Robertson 2012). The mobility approach asserts that these contexts are not neutral backdrops or convenient landing places, rather they are co-constitutive social spatial contexts able to produce "hybrid mutations of policy techniques and practices across dynamized institutional landscapes" (Peck 2011, p. 2), including scale, territory, place, locality and the global (Cochrane and Ward 2012). One of the methodological challenges in studying mobile policies is to follow them, to trace their twists and localized effects. In essence, this requires an ability to trace power through the set of relations associated with policy mobility and mutation from one context to another.

\subsection{Constitutive Localization}

Wider policy networks are important to the construction of local responses, while at the same time globalized policies are only capable of realization in particular grounded and localized ways (Cochrane and Ward 2012). Globalized policies find their expression and are given their meaning in local contexts and that local 
translation then feeds back into further circulation. Acharya (2009) uses the concept of 'constitutive localization' to denote processes of re-interpreting and re-representing the external policy norms to make them congruent with existing local beliefs and practices. The key aspect of the localization is the agency of the norm recipients, who are not merely passive norm takers, paving the way to a wholesale cognitive transformation. Much more often, they respond proactively to normative challenges through framing, grafting and pruning with an aim to transform them into 'domestic fit' (Acharya 2009; Rüland 2014a). The connections between the external ideas/norms/policies and local circumstances are not always obvious. Framing is about using language that names, interprets, redefines and reconstructs external ideas in order to create linkages between existing 'cognitive priors' and emergent norms. Grafting is a tactic employed to institutionalize a new norm to suit their local needs and values. Pruning is to cut and leave out some elements of the external policy norms, or sometimes local norms also need to be pruned. For example, assuming regional leadership role, Indonesian stakeholders remove the supranational dimension from the European model, but they also support the formal ASEAN Charter which challenges the non-interference norm and prunes the informal 'ASEAN Way' (Rüland 2014b). In other words, local actors play an important role in the construction of regions because they both resist and are socialized within its structures. They interact with, and simultaneously rework social meaning of new policies (Emerson 2014). These processes are also termed as 'Discursive Opportunity Structures' (DOS) which local actors utilise to identify ideas in the larger political context, that are believed to be 'sensible', 'realistic' and 'legitimate' and that facilitate the reception of certain types of framing (Koopmans and Staham 1999; McCammon et al. 2007, p. 731). 'Discursive Opportunity Structures' are different from plain 'Opportunities'. The concept of DOS is closely linked with social movements and contains three key features: (1) variations in opportunity determine variations in collective actions; (2) relevant variations in opportunity result mainly from the interaction with political actors and institutions; (3) variations in such opportunities are structurally shaped (Koopmans 1999). DOS can be highly stable structures if collective actions stem from discourses long-lived and deeply rooted in the surrounding culture, and they can be volatile structures if collective actions derive from short-lived and new ideation. All DOS are inherently selective and therefore it is important for local actors to identify which DOS provide fertile ground for only a narrow range of actions, and which DOS select a wider range (McCammon et al. 2007). Successful localizers are those able to mobilise local sources for their action, such as structural characteristics of political system, the behaviours of allies, adversaries, and the public; societal 'moods'; economic structures and developments; cultural myths and narratives.

It is also important to distinguish adaptation and localization. Adaptation tends to generate adaptive behaviours and make local practices consistent with external ideas. Localization, by contrast, describes a process in which external ideas are adapted to suit local practices (Acharya 2009, p. 19). Localization is often a long term and evolutionary process, while adaptation in international relations literature is seen as 'short run policy and accommodation'. Thus, adaptation may be tactical 
and to a certain extent forced on the recipients, whereas localization is voluntary and the resulting change is likely to be more enduring. These aspects of localization render it constitutive.

In sum, the integration of policy diffusion, polity mobility and localisation delineates a useful theoretical framework to understand how ASEAN regional higher education policies have been made in the EU-ASEAN interactions.

\section{ASEAN Regional Harmonisation of Higher Education}

From around 2008, when Europe talked much about the establishment of the European Higher Education Area (EHEA), the phrase 'ASEAN Common Space for Higher Education' started to appear in the media and ASEAN policy documents (Sirat 2008). Perhaps the conception of an ASEAN education space is not without precedent because already in 1971 a regional European Education Space was conceived by a working group called the European Centre for the Development of Education (Lawn 2003). However, the ASEAN concept of common space for higher education has its own connotations and meanings resulted from localization processes. Senior officials from ASEAN countries share their personal views on 'common space', which is associated with an ASEAN concept of harmonization. By contrast, harmonization is a taboo word in the Bologna Process (Garben 2010; Zgaga 2003). So far, ASEAN higher education regionalization is not about achieving a highly standardized higher education zone as in the Bologna Process. It is not about making drastic changes to the national higher education systems, but rather aiming for harmonization, which allows diverse systems to be linked at points of junction. The underlying fact is that the ASEAN region is characterized by great diversity of political regimes, levels of development, religions, education traditions and gaps in quality. Kuroda (2009) described the EHEA as 'melting pot harmonization' which required structural changes of domestic higher education systems, and ASEAN higher education space is 'mosaic harmonization', which requires prudent steps of collaboration to seek points of linkages. Despite the differences that could possibly divide, there are also other factors that can unite the members of ASEAN+3 to arrive at some sort of affinity (Koh 2007, p. 9). Student mobility is an example of such unitive factors.

Inspired by the European Union Erasmus mobility programmes, the ASEAN+3, countries have launched CAMPUS Asia (Collective Action for Mobility Program of University Students in Asia) and AIMS (ASEAN International Mobility for Students). Although CAMPUS Asia is a 'credit mobility' programme for students among all 13 countries in the ASEAN+3 region, it is not a 'twin brother' of the Erasmus programme due to several reasons.

First, CAMPUS Asia is one part of the 5-year strategic project called "Re-Inventing Japan". Originating from an agreement at the China-Korea-Japan Heads of State Summit in 2009, this idea was followed up and led by Japan with the support from China and Korea. CAMPUS Asia was developed and launched in 
2011 by the Japanese Ministry of Education, Culture, Sports, Science and Technology (MEXT). Their national aim is to extend the international reach of Japanese universities by building connections with higher education institutions throughout Asia, the United States and other Western countries.

Second, the Erasmus programme is about short term mobility without joint or dual degree arrangements, whereas CAMPUS Asia focuses more on the latter. While the conventional internationalization of universities in Japan entails increasing number of incoming international students and outgoing Japanese students, and providing more courses taught in English, the recent strategies have focused more on transnational collaboration; setting up joint programmes and research projects (Yamada 2013). In fact, CAMPUS Asia consists of two components with different motives. The first component, perhaps similar to Erasmus Mundus, is to establish consortia of leading universities from Japan, China and the Republic of Korea to implement the strategic Northeast Asia region building through higher education ties. The name CAMPUS Asia is thus far attached more to this triangular mobility scheme. The second component is the exchange projects organized in a 'hub-and-spoke' model between Japan (being the hub) and universities in ASEAN and in China and Korea which are not covered in the above trilateral framework. However, in practice, the focus of Re-inventing Japan was twisted in 2012 to prioritize collaboration with ASEAN countries. This is evident in the number of approved projects consisting of 120 ASEAN partner universities in 2012 and 45 ASEAN partner universities in 2013 exchanging students with Japan at programme level (Re-inventing Japan 2012, 2013). In fact, the selected projects in these two years were almost exclusively for collaboration of Japanese universities with ASEAN universities. ${ }^{3}$ This shift of priority occurred at the same time as the ASEAN+3 countries intensified their educational cooperation with ASEAN and prepared for the first ASEAN+3 Education Ministers' meeting with the ASEAN ministers in 2012. This also coincides with the EU Erasmus+ project which was devised with a bigger budget, a larger scale and more aggressive 'external dimension'. Thus, the need to establish an ASEAN+3 region and an intra-regional mobility scheme became more urgent in order to act as regional partner with the EU. It also becomes clear that such regional policy contexts, policy moments and the policy actions of Japan are constitutive elements of the circulatory systems which facilitate the Bologna regionalism ethos to ASEAN. A senior official shared his view on building an ASEAN+3 region through student mobility and establishing a higher education quality assurance centre for Asia.

We have CAMPUS Asia and AIMS programme for mobility in Southeast Asia. I think we can connect those first. ... [we do not have the European Commission] but we have ASEAN+3, a framework already. At the ASEAN+3 meeting on mobility in Tokyo in September 2013 we set up a working group. The next meeting will be in Bali in October 2014. The chair is from an ASEAN country and the co-chair will be from the 'Plus three'

${ }^{3}$ Re-Inventing Japan Project - Selection results for 2012, 2013, 2014

http://www.jsps.go.jp/j-tenkairyoku/kekka.html

http://www.mext.go.jp/english/highered/1326678.htm (accessed 15 September 2014). 
countries. And Japan is the organizer of the first meeting, so we were setting the agenda and making the documents. We are trying to help the working group. So we are a kind of coordinator in this project.

(The author's interview with Ministerial Senior Official, Japan, May 2014)

Both components of CAMPUS Asia are intended to facilitate incoming and outgoing mobility across systems. Therefore, the policy tools, such as quality assurance and recognition of qualifications across the region became an important issue and the Bologna Process seems to have provided some solutions. However, it would be implausible to conclude that CAMPUS Asia replicates Erasmus and Bologna ideas by counting on the emergence of the scheme only. A closer look at the operation and the governance of CAMPUS Asia reveals marked differences from Erasmus. For example, while the Erasmus grants come from the common European funds in Brussels distributed through the sending country's Erasmus National Agency, the scholarship for students in CAMPUS Asia is granted by the host university with the funding from the host government. The mobility track of Erasmus is more flexible and based on any bilateral agreements between eligible universities in two different countries, whereas the mobility track of CAMPUS Asia is limited within a fixed consortium with varying study durations of one or more semesters leading to an exchange certificate or a dual diploma respectively. The governance of each consortium is similar to the model of the Erasmus Mundus joint masters' programs, but many CAMPUS Asia consortia cover all three cycles (bachelor, masters and doctoral). These consortia represent the participating countries' (and region's) leading universities with cutting edge research in their specialized fields. CAMPUS Asia also has many motives. Region-building (ASEAN+3), regional competitiveness enhancement, foreign policy (peace building, especially between Northeast Asian countries) and cultural exchanges are, thus, seen as 'logics of [educational] intervention' in the words of Dale and Robertson (2012).

From a different starting point and objective, the AIMS project is a short-term mobility scheme among ASEAN countries with the purpose of 'cultural enrichment' and less of 'academic advancement'. Launched in 2010 as a pilot mobility scheme between Malaysia, Indonesia and Thailand, three years later AIMS has involved around 700 students mobile among 60 universities from seven ASEAN countries, including Japan (Sujatanond 2014). The financial support for AIMS is allocated to the sending universities by their ministries. Perhaps one of the "harmonization effects resulted from AIMS is that Thailand and the Philippines have changed their academic calendars to begin in August and September from 2014 in order to be in harmony with most other ASEAN countries (Chao 2014b). However, AIMS has been facing numerous obstacles, such as unsettled schemes for credit transfers and recognition of study period/academic modules, staff capacity, and readiness of universities, coordination, and funding. In some ways, it mirrors the version of Erasmus in its very early days, more than 20 years ago. An Asian expert shared the story about the rationale to start AIMS:

The background is that we talked much about regionalization, but nobody set the mandate. During a retreat in 2009, the Thai, Malaysian and Indonesian High Commissions for higher 
education started to talk about what we can do together. ASEAN is about people-to-people connectivity, therefore we started with students first because these people are willing to learn and willing to explore [...].We should choose something that we can handle and can really do together. [...] 'ASEAN Research Clusters and Citation Index' is the last point added to the regional agenda because research is difficult to do".

(The author's interview with Asian senior expert, May 2014)

This 'Erasmus-like' project displays a logic of diffusion that has less to do with the noble notion of optimal decision making, because ASEAN policy makers are conceived of as learning agents, working within the constraints of bounded rationality and context. Sometimes, a policy maker is a social engineer seeking knowledge instrumentally and his lesson-drawing is ultimately about whether policies can be transferred from one place to another (Peck 2011). The costs and capacity constraints induce policy makers to pursue the lines of least resistance, rather than searching endlessly for ideal policy solutions. Lesson drawing in this case also entails looking for shortcuts and acceptable compromises. Policy learning is thus an instrumental process.

These two examples shed light on the weakness of the diffusion literature that is primarily concerned with observed or alleged convergence, which are usually judged on the surface similarities in policy designs and normative rationales (Peck and Theodore 2010). In practice, the Erasmus mobility programme mutated into very different versions in Asia. One of the reasons for this policy mutation is the 'localization' process in ASEAN as illustrated below.

The political practices of ASEAN governments are strongly influenced by their 'cognitive priors', which tell us how external norms are considered appropriate and legitimate. This practice is reflected in the way Asian policy actors are making connections between foreign discourses and the local ideas and values.

\footnotetext{
We don't want to use the word 'regionalize' because it is like you are departing (detaching) yourself from the rest to be a region of your own. [...]

'Harmonization' is not about imposing on member countries, but only trying to harmonize what already exists in such a way that there is a common area, sort of overlap, which can be recognized by all the members. That is why the word 'harmonization' is preferred in our region. It is like an orchestra, everyone uses one instrument, but together they create a piece of music in harmony.

(The author's interview with Asian senior expert, May 2014)
}

The policy networks are relational constructs, their efficacy depends on local political conditions (Peck 2011). While the EHEA is about a common set of rules and standards for higher education, common space in ASEAN is about opening your doors to your neighbours.

Harmonization is about creating harmony, sharing information and experience in higher education. Student mobility is a part of a regional harmonization project. When students move between member countries, universities have to open their doors and show that their system is in harmony and keep pace with other countries. In order to receive international students, we have to improve our quality and adjust our higher education to be in harmony with the region.

(The author's interview with Ministerial Senior Official, Vietnam, May 2014) 
The term 'open door' is literally taken from a powerful policy discourse in Vietnam, when the country began to re-integrate in the international system after the lift of the U.S. embargo. By using this language, the actor has tapped into the larger system of meaning and even extended specific aspects of ideological orientations (McCammon et al. 2007) to make it appear local and politically persuasive. The localizers also have their own way of selecting some 'discursive opportunities' to frame the issue in ASEAN and prepare fertile ground for proposing new norms. In essence, the policy localizers use lesson-drawing to attack the status quo with evidence that feasible and potentially superior alternatives exist elsewhere.

when you talk about mobility and harmonization then you need something in common. I remember my student time in the US, there was a 'common room' where people can do different activities together without annoying other friends. Everybody can go along very well in the common room. Let's take the example of recognition of qualifications; a Vietnamese student graduated from a bachelor programme in Vietnam, then studied a masters' degree in continental Europe and a PhD degree in the UK. That raises the question why we [ASEAN] do not/cannot do it in the region. Why don't we [ASEAN] open our systems to other members and help students to gain cross cultural understanding?

(The author's interview with Asian senior expert, May 2014)

Departing from the idea of harmonization and common space, the vision for a regional higher education has moved towards a more macro level addressing the underlying goal of regional competitiveness. The viewpoint below indicates that, while discursive opportunity structures are apparent in the broader context, in the end the policy actors are agents who make decisions about how to respond to such opportunities (McCammon et al. 2007). The expression also implies that opportunity structure is socially constructed, and that collective actors who can articulate frames to fit with this discursive structure are more likely to be politically effective.

Common space for higher education has to be some kind of common understanding, a common platform because ASEAN has to compete with all the other regions in the world [...]. We can define the space and make sure that the participants are able to come up with learning skills that are appropriate for us to compete well. Common space here is more about the mind set and a common set of objectives, something that we will pursue together. Ten countries in ASEAN are doing the same thing so that we can excel.

(The author's interview with Ministerial Senior Official, the Philippines, May 2014)

In practice, this goal of enhancing the region's competitiveness has great potential to shape and construct new policy landscapes in ASEAN. For example, the novel policy idea on ASEAN Clusters and Citation Index is the 'youngest' item on the regional agenda, beyond the student mobility. In 2010, Thailand proposed pioneering ASEAN Research Clusters and explored the possibility of setting up an "ASEAN Citation Index (ACI)". The initial objectives are to (a) compile national journal databases in ASEAN countries, (b) enhance the quality of research, (c) increase ASEAN academic visibility in the region and beyond. The recent structure was set up in an 'ASEANess institutional model'-multilateral and inter-governmental cooperation instead of central supranational institution. The Thai Ministry of Education provides funding for the project and the Thai Journal 
Citation Index Centre (TCI) set up the ACI database. The database serves two purposes: (1) selecting outstanding journals from each country based on an agreed set of criteria and (2) enhancing cooperation between ACI and Scopus-the worldwide database of academic journals and books (the author's interview with Ministerial Senior Official, Thailand, May 2014).

Although this initiative does not look like it has been taken from the Bologna model, it has some traits similar to the British Research Excellence Framework (REF), especially the ranking of academic journals. It is a first step toward an ASEAN common space for research and predictably, a terrain for new public management discourse, to which ASEAN member countries subscribe. This, in turn, will transform the policy landscape in the region because policy mobility and mutation proceed in tandem and in on-going transformative processes (Peck and Theodore 2010). The new forms and effects of this regional policy are to be seen.

\section{An Alternative Regional Model and Inspiration for EU-ASEAN Inter-regional Cooperation}

This contribution has sought to introduce a new approach to examining the influence of the Bologna Process on a regional scale outside Europe by analyzing the contexts, local policy actors and policy substance at the receiving end. The policy diffusion literature provides a framework for explaining different mechanisms for rational diffusion and best practice replication, but this approach focuses narrowly on the action of policy exporters and the surface convergence of policy. The discussion of policy mobility provides a more convincing explanation of relational interconnectedness between the constitutive power of policy context and agency to mutate the policy outcomes. The Bologna policies have not travelled intact from Europe to Asia but have been transformed through networks of actors and shifting policy landscapes.

Although it seems that the Bologna Process provides points of reference for ASEAN, the active construction of an ASEAN regional higher education space in its flexible institutional design can arguably become a model in its own right and potentially provide a useful source for reflecting on European Bologna practices. ASEAN has long been perceived by its member states as an organization that has been set up in a manner that was essentially different from the EU (Jetschke and Murray 2012), and Asian regionalism (also with regard to higher education) continues to remain closely tied to the soft and non-binding "ASEAN way". The 'coercive' - albeit voluntaristic - character of the Bologna Process and its Open Method of Coordination using regional standards, benchmarks and peer pressure would have little use in making sense of ASEAN regional cooperation. Hence, it would be implausible to assume that Bologna experience sets the criteria by which ASEAN higher education harmonization should be measured. 
This paper has also demonstrated that increasing policy mobility needs not imply policy convergence simply because policies will mutate in the course of their travels from one jurisdiction to another, and the policy actors and their peripatetic forms of expertise are likewise transformed by the journeys that they make (Peck 2011). Hence, there is no policy monopoly because new forms of uneven spatial development and new localizations are constantly being produced. Moreover, if bi-regionalism in a hub-and-spokes relationship model is what the EU builds with other regions, such as ASEAN, Africa and Latin America (Rüland 2010), this hub-and-spokes model is dynamic because regions can change their position as a hub. In practical terms, the CAMPUS Asia university consortia would undoubtedly become strategic partners for the cooperation with European universities under the new ERAMUS+ scheme in the coming years. Stated differently, other 'external' world regions' endeavours may affect the future of the Bologna Process and give impulse to the 'internal' consolidation of EHEA in the race for competitiveness and attractiveness. ASEAN goals and norms have the potential to offer an alternative to the European prevailing institutionalized model (Stubbs 2008) that in the medium to long term could have an impact on the global governance the higher education sector.

Acknowledgement I would like to thank Margarita Ulloa, Professor Roger Dale, Dr. Chris Muellerleile, Corina Balana, Hazel Price and Sjur Bergan for their helpful comments on earlier versions of this paper. I am also grateful to all the interviewees for their insightful information. Research for this contribution was made possible through the European project "Universities in the Knowledge Economy - UNIKE" and the scholarship provided by the EU Marie Curie Action, for which I gratefully acknowledge.

Open Access This chapter is distributed under the terms of the Creative Commons Attribution Noncommercial License, which permits any noncommercial use, distribution, and reproduction in any medium, provided the original author(s) and source are credited.

\section{References}

Acharya, A. (2009). Whose ideas matter? Agency and power in Asian regionalism. Ithaca and London: Cornell University Press.

Allison, L. (2013). Preaching regionalism? Norm diffusion in the EU-ASEAN relationship. (PhD thesis), School of Social and Political Sciences, University of Melbourne.

APT. (2014). Joint statement of the second ASEAN plus three education ministers meeting. http:// www.asean.org/news/asean-statement-communiques/item/joint-statement-of-the-second-aseanplus-three-education-ministers-meeting?category_id=26

ASEAN. (2009). Chairman's statement of the 15th ASEAN summit - enhancing connectivity, empowering peoples. http://www.asean.org/news/item/chairman-s-statement-of-the-15thasean-summit-enhancing-connectivity-empowering-peoples

ASED. (1977). Joint Communique of The First ASEAN education ministers meeting Manila, 8-9 Dec 1977. http://www.asean.org/news/item/joint-communique-of-the-first-asean-educationministers-meeting-manila-8-9-december-1977 
ASED. (2010). Joint statement of the fifth ASEAN education ministers meeting. http://www.asean. $\mathrm{org} /$ news/item/joint-statement-of-the-fifth-asean-education-ministers-meeting-5th-ased-cebu-cityphilippines-28-january-2010

ASED. (2014). Joint statement of the eighth ASEAN education ministers meeting. http://www. asean.org/news/asean-statement-communiques/item/joint-statement-of-the-eighth-aseaneducation-ministers-meeting-8th-ased?category_id=26. Accessed 23 Dec 2014.

Bergen Communique. (2005). The European higher education area-achieving the goals. http:// www.ehea.info/Uploads/Declarations/Bergen_Communique1.pdf

Berlin Communique. (2003). Realising the European higher education area. http://www.ehea.info/ Uploads/about/Berlin_Communique1.pdf

BFUG. (2002). Attractiveness, openness and cooperation. The European higher education area and third countries. Report by the Danish Presidency, first draft on 4 November 2002. Copenhagen: Danish Presidency.

Börzel, T., \& Risse, T. (2009). Diffusing (inter-) regionalism: The EU as a model of regional intergration, $K F G$ working paper no. 7. Berlin: Freie University Berlin.

Börzel, T., \& Risse, T. (2012). When Europeanisation meets diffusion: exploring new territory. West European Politics, 35(1), 192-207.

Chao, R. (2014a). Pathways to an East Asian higher education area: A comparative analysis of East Asian and European regionalization processes. Higher Education.

Chao, R. (2014b). Harmonising academic calendars: A student mobility tool? In University World Newsx (p. 317), 25 Apr.

Clark, N. (2014). The Bologna process as a model for regional integration. In World education news \& review, 3 June.

Cochrane, A., \& Ward, K. (2012). Guest editorial: Researching the geographies of policy mobility: Confronting the methodological challenges. Environment and Planning A, 44(1), 5-12.

Dale, R., \& Robertson, S. (2012). Towards a critical grammar of education policy movements. In Gita Steiner-Khamsi \& Florian Waldow (Eds.), World yearbook of education 2012: Policy borrowing and lending in education (pp. 21-40). London and New York: Routledge.

Dang, Q. (2013). ASEM - the modern silk road: Travelling ideas for education reforms and partnerships between Asia and Europe. Comparative Education, 49(1), 109-117.

Dent, C. (2012). The century belongs to all of us: East Asia regionalism and world society. In C. Dent \& J. Dosch (Eds.), The Asia Pacific regionalism and the global system. Edward Elgar.

DiMaggio, P., \& Powell, W. (1983). The Iron Cage Revisited: Institutional Isomorphism and Collective Rationality in Organizational Fields. American Sociological Review, 48(2), 147-160.

Doidge, M. (2011). The European union and interregionalism: Patterns of engagement. Ashgate Publishing.

Emerson, R. (2014). An art of the region: Towards a politics of regioness. New Political Economy, 19(4), 559-577.

EU SHARE. (2014). EU support to higher education in ASEAN region (EU SHARE), Guidelines for grant applicants.

Garben, S. (2010). The Bologna process: from a European law perspective. European Law Journal, 16(2), 186-210.

Hettne, B. (2005). Beyond the 'new' regionalism. New Political Economy, 10(4), 534-571.

ICEF. (2014). ASEAN poised to usher in new era of regional student mobility, $21 \mathrm{Jan}$. http://monitor. icef.com/2014/01/asean-poised-to-usher-in-new-era-of-regional-student-mobility/. Accessed 23 Dec 2014.

Jetschke, A., \& Lenz, T. (2013). Does regionalism diffuse? A new research agenda for the study of regional organizations. Journal of European Public Policy, 20(4), 626-637.

Jetschke, A., \& Murray, P. (2012). Diffusing regional integration: The EU and Southeast Asia. West European Politics, 35(1), 174-191.

Kamibeppu, T. (2013). Effects and influences of the Bologna process on Japan and beyond. Paper presented at the external dimension of the Bologna Process, Dresden, 8-9 Oct 2013. 
Koh, A. (2007). Deparochializing education: Globalization, regionalization, and the formation of an ASEAN education space. Discourse: Studies in the Cultural Politics of Education, 28(2), 179-195.

Koopmans, R. (1999). Political. Opportunity. Structure. Some splitting to balance the lumping. Sociological Forum, 14(1), 93-105.

Kuroda, K. (2009). Possibilities and challenges in constructing a new regional collaboration educational framework in Asia. Working Paper 2009-E-1. Global Institute for Asian Regional Integration, Waseda University.

Lawn, M. (2003). The 'usefulness' of learning: The struggle over governance meaning and the European education space. Discourse, 24(3), 325-336.

McCammon, H., Muse, C., Newman, H., \& Terrell, T. (2007). Movement framing and discursive opportunity structures: The polictical successes of the U.S. Women's July movements. American Sociological Review 72, 725-749.

Narine, S. (1998). Institutional theory and Southeast Asia: The case of ASEAN. World Affairs, 161 (1), 33-47.

Peck, J. (2011). Geographies of policy: From transfer-diffusion to mobility-mutation. Progress in Human Geography, 1-25.

Peck, J., \& Theodore, N. (2010). Mobilizing policy: Models, methods and mutations. Geoforum, $41,169-174$.

Peck, J., \& Theodore, N. (2012). Follow the policy: A distended case approach. Environment and Planning, 44, 21-30.

Re-inventing Japan. (2012). Selected mobility programs with ASEAN universities. http://www. jsps.go.jp/j-tenkairyoku/data/shinsa/h24/H24_tenkai_kekka_e.pdf. Accessed 23 Dec 2014.

Re-inventing Japan. (2013). Selected mobility programs with ASEAN universities. http://www. jsps.go.jp/j-tenkairyoku/data/shinsa/h25/h25_tenkai_kekka_eng.pdf. Accessed 23 Dec 2014.

Rüland, J. (2010). Balancers, muiltilateral utilities or regionsal identity builders? International relations and the study of interregionalism. Journal of European Public Policy, 17(8), 12711283.

Rüland, J. (2014a). The limits of democratizing interest representation: ASEAN's regional corporatism and normative challenges. European Journal of International Relations, 20(1), 237-261.

Rüland, J. (2014b). Constructing regionalism domestically: Local actors and foreign policymaking in newly democratised Indonesia. Foreign Policy Analysis, 10, 181-201.

Rüland, J., \& Jetschke, A. (2008). 40 years of ASEAN: Perspectives, performance and lessons for change. The Pacific Review, 21(4), 397-409.

Sirat, M. (2008). Towards harmonisation of higher education in Southeast Asia: Malaysia's perspective. http://globalhighered.wordpress.com/2008/10/21/towards-harmonisation-of-highereducation-in-southeast-asia/. Accessed 23 Dec 2014.

Solingen, E. (2012). Of dominoes and firewalls: The domestic, regional, and global politics of international diffusion. International Studies Quarterly, 56, 631-644.

Stubbs, S. (2008). The ASEAN alternative? Ideas, institutions and the challenge to "global" governance. The Pacific Review, 21(4), 451-468.

Sujatanond, C. (2014). Student mobility enhancement ASEAN international mobility for students (AIMS) programme, presentation by the special advisor to SEAMEO RIHED. Paper presented at the 8th Meeting of Directors General/Secretary General/Commissioner of Higher Education in Southeast Asia, Ho Chi Minh City, Vietnam, 27 May 2014.

Temenos, C., \& McCann, E. (2013). Geographies of policy mobilities. Geography Compass, 7(5), 344-357.

Vögtle, E., \& Martens, K. (2014). The Bologna process as a template for transnational policy coordination. Policy Studies, 35(3), 246-263.

Wong, B. (2012). Model power or reference point? The EU and the ASEAN charter. Cambridge Review of International Affairs, 25(4), 669-682. 
Yamada, R. (2013). Chapter 10 structural transformation of Japanese higher education: Adopting to meet challenges posed by globalisation and market economy. In D. Neubauer, J. Cheol shin \& J. N. Hawkins (Eds.), The dynamics of higher education development in East Asia: Asian cultural heritage, western dominance, economic development, and globalization. New York: Palgrave Macmillan.

Yeo, L. H. (2010). Institutional regionalism versus networked regionalism: Europe and Asia compared. International Politics, 47(3/4), 324-337.

Zgaga, P. (2003). Reforming the curricula in universities of South East Europe in view of the Bologna process. Higher Education in Europe, 28(3).

Zgaga, P. (2006). Looking out: The Bologna process in a global setting: On the "external dimension" of the Bologna process. Norway: Norwegian Ministry of Education and Research. 